\title{
Cyclic nucleotide phosphodiesterases in somatic and germ cells of mouse seminiferous tubules*
}

\author{
P. Rossi†, R. Pezzotti, M. Conti and R. Geremia $\uparrow$ \\ $\dagger$ Department of Public Health and Cell Biology, II University of Rome, and Institute of Histology \\ and General Embryology, I University of Rome, Italy
}

\begin{abstract}
Summary. The distribution of phosphodiesterase forms in somatic and germ cells, and their variations during testicular development and germ cell differentiation have been investigated. Seminiferous tubules from immature mice and Sertoli cells in culture possessed two enzyme activities which were comparable to forms described for different tissues and species: (a) a calcium-calmodulin-dependent enzyme with high affinity for guanosine $3^{\prime}, 5^{\prime}$-(cyclic)-monophosphate (cGMP), and (b) a calciumcalmodulin-independent enzyme with high affinity for adenosine 3',5'-(cyclic)monophosphate (cAMP) the activity of which increased in cultured Sertoli cells after treatment with FSH or dibutyryl cAMP. Seminiferous tubules from adult animals and germ cells at the meiotic and post-meiotic stage of differentiation possessed two enzyme forms that could be distinguished from those present in somatic cells of the seminiferous tubules: (a) a calcium-calmodulin-dependent form with high affinity for both cAMP and cGMP, similar to forms described in other tissues from different species, and (b) a calcium-calmodulin-independent phosphodiesterase with high affinity for cAMP and present only in post-meiotic cells, previously identified also in germ cells of the rat.
\end{abstract}

\section{Introduction}

It is well documented that cyclic nucleotides play multiple roles in the regulation of testicular function. In somatic cells they mediate Sertoli and Leydig cell response to gonadotrophins (as reviews see: Means et al., 1980; Purvis \& Hansson, 1980). At the level of the germ cells, they are thought to be involved in the control of sperm maturation in the epididymis (see Sanborn, Heindel \& Robison, 1980, for review). Furthermore, the observation that high levels of cAMP cause a reduction in spermatogonial divisions (Hollinger \& Hwang, 1974) and inhibition of spermiation (Gravis, 1978) suggests a participation of cyclic nucleotides in the control of male germ cell differentiation in the seminiferous tubules either acting directly within the germ cells or via the mediatory role of Sertoli cells. The hypothesis that cyclic nucleotides participate in the control of germ cell differentiation is further strengthened when it is considered that high cAMP concentration is required to prevent resumption of meiosis in amphibian and mammalian oocytes (Morrill, Zeigler \& Kostellow, 1981; Schultz, Montgomery \& Belanoff, 1983) and to prevent the onset of meiosis in yeast (Matsumoto, 1983).

Cyclic AMP level in the seminiferous tubules is regulated in a complex fashion as indicated by studies in different cell types. It varies in germ cells at different stages of differentiation (Spruill \& Steiner, 1976; Adamo, Conti, Geremia, Boitani \& Monesi, 1980a) and in Sertoli cells, according to the age of the animal (Means et al., 1980) or to the refractory state after FSH treatment (Verhoeven,

\footnotetext{
* Reprint requests to: Professor R. Geremia, Dipartimento di Sanità Pubblica, Il Università di Roma, "Torvergata", Via O. Raimondo, 00173 Roma, Italy.
} 
Cailleau \& De Moor, 1980; Conti, Toscano, Petrelli, Geremia \& Stefanini, 1983b). It has been suggested that intracellular levels of cAMP are regulated in germ cells by changes of phosphodiesterase activity (Geremia, Rossi, Pezzotti \& Conti, 1982) on the basis of the observation that these cells possess an adenylate cyclase activity which is $\mathrm{Mn}^{2+}$-dependent, and $\mathrm{NaF}$ - and hormone-insensitive (Braun, 1974; Adamo, Conti, Geremia \& Monesi, 1980b; Gordeladze \& Hansson, 1981), and whose activity does not correlate with the level of cAMP (Adamo et al., 1980a). The importance of catabolism in the regulation of cAMP levels in Sertoli cells has been emphasized: phosphodiesterase variations would be involved in the age-dependent modifications of the response to FSH and in the development of a refractory state after hormone stimulation (Means, Dedman, Tindall \& Welsh, 1978; Spruill, Steiner, Tres \& Kierszenbaum, 1981; Conti, Geremia, Adamo \& Stefanini, 1981; Verhoeven et al., 1981; Conti et al., 1982, 1983a, b).

The present study on phosphodiesterase forms in mouse testis has been performed with the aim of defining their distribution in somatic and germ cells, their variation during testicular development and germ cell differentiation, and the mechanisms of their regulation. A preliminary report of this work has been published in abstract form (Geremia, Mocini, Pezzotti, Conti \& Rossi, 1983a).

\section{Materials and Methods}

Biological materials. Male Swiss CD1 mice were used in all experiments. Seminiferous tubules were freed of interstitial tissue by collagenase treatment at room temperature in Dulbecco's phosphatebuffered saline (PBS) followed by several washes by sedimentation in PBS (Geremia, D'Agostino \& Monesi, 1978). Total germ cell suspensions were obtained by trypsin treatment of seminiferous tubules from 60-day-old animals (Geremia et al., 1978). Germ cells at defined stages of differentiation were obtained by sedimentation velocity fractionation at unit gravity in albumin gradients of the cell suspensions (Lam, Furrer \& Bruce, 1970). Germ cell fractions (80-90\% homogeneous) containing middle-late pachytene spermatocytes, round spermatids at steps 1 to 8 of spermiogenesis and intermediate spermatids at steps 9 to 13 of spermiogenesis were used. Cell fractions were washed twice in PBS before use. Sertoli cell cultures from 20-day-old mice were performed as previously described for the rat (Dorrington, Roller \& Fritz, 1975) and were maintained in Minimum Essential Medium with Earle's salts (Gibco, Paisley, Scotland) at $32^{\circ} \mathrm{C}$ in a controlled atmosphere of air and $5 \% \mathrm{CO}_{2}$. After 3 days of culture Sertoli cell monolayers were briefly exposed to $20 \mathrm{~mm}$-Tris-(hydroxymethyl)-methylamine (Tris- $\mathrm{HCl}$ ) $\mathrm{pH} 7 \cdot 4$ hypotonic solution to remove remaining germ cells (Galdieri, Ziparo, Palombi, Russo \& Stefanini, 1981). At $24 \mathrm{~h}$ after germ cell removal, Sertoli cell monolayers were treated for $24 \mathrm{~h}$ with dibutyryl cyclic AMP (dbcAMP) (Sigma, St Louis, MO, U.S.A.) or FSH (NIADDK-ovine-FSH-S15). Spermatozoa were prepared from the caput and cauda epididymidis as described by Majumder (1978). Epididymides were cut with a razor blade and the fragments were gently stirred at room temperature for $30 \mathrm{~min}$ in PBS. The resulting suspension of spermatozoa was separated from epididymal fragments by sedimentation at unit gravity and then washed twice by centrifugation.

Cytosol preparation. Seminiferous tubules, germ cells, Sertoli cell monolayers or spermatozoa were homogenized at $4^{\circ} \mathrm{C}$ with 15 strokes in a Dounce homogenizer in 4-5 volumes of 20 mM-Tris$\mathrm{HCl}, \mathrm{pH} 8,10 \mathrm{~mm}$-2-mercaptoethanol, $2 \mathrm{~mm}$-phenylmethylsulphonylfluoride and 0.2 mM-ethyleneglycolbis-(aminoethylether)-tetra-acetic acid (EGTA), unless otherwise stated in 'Results'. The homogenate was then centrifuged for $15 \mathrm{~min}$ at $20000 \mathrm{~g}$ and $1 \mathrm{~h}$ at $105000 \mathrm{~g}$. The supernatant thus obtained is referred to as cytosol. Protein content was determined with a modification of the method of Lowry (Bensadoun \& Weinstein, 1976).

Ion-exchange chromatography. DEAE-cellulose chromatography (DE52, Whatman) was performed at $4^{\circ} \mathrm{C}$ essentially as described elsewhere (Geremia et al., 1982). Columns $(0.6 \times 10 \mathrm{~cm})$ 
were equilibrated with $70 \mathrm{~mm}$-sodium acetate, $\mathrm{pH} 6.5,5 \mathrm{~mm}-2$-mercaptoethanol and $0.2 \mathrm{~mm}$ EGTA. Cytosol containing 3-5 mg protein was applied to columns after a $1: 4$ dilution with equilibration buffer. After washing with 4 column volumes of the same buffer, elution was performed with a linear sodium acetate gradient (70-600 mM) containing $10 \mathrm{~mm}$-2-mercaptoethanol and $0.2 \mathrm{mM}-E G T A$ at a constant flow rate of $0.25 \mathrm{ml} / \mathrm{min}$. Fractions of $0.5 \mathrm{ml}$ were collected in tubes containing $50 \mu 10 \cdot 1 \%$ bovine serum albumin. Recovery of activity ranged between 80 and $90 \%$. Chromatographic separation of enzyme activity was performed in the presence of chelating agents to minimize the formation of calcium-calmodulin-enzyme complexes which would elute at a different ionic strength with respect to the free enzyme.

Phosphodiesterase assay. Enzyme activity was measured as conversion of cAMP and cGMP to their respective 5'-nucleotides, according to the method of Thompson \& Appleman (1971). The incubation mixture, in a final volume of $200 \mu \mathrm{l}$, contained $20 \mathrm{mM}-\mathrm{Tris}-\mathrm{HCl}, \mathrm{pH} 8,5 \mathrm{mM}-\mathrm{MgCl}_{2}$, 5 mM-2-mercaptoethanol, 0.1 mM-EGTA, $1 \mathrm{~mm}-\mathrm{CaCl}_{2}$, and, when stated in 'Results', $3 \mu \mathrm{g}$ purified calmodulin (Jamieson \& Vanaman, 1979). Cyclic AMP and cGMP were used at a final concentration of $1 \mu \mathrm{M}$ (containing 100000 c.p.m. $\left[{ }^{3} \mathrm{H}\right]$ nucleotide/tube, routinely purified by gel filtration). The reaction was performed at $34^{\circ} \mathrm{C}$ and stopped by adding $200 \mu \mathrm{l} 40 \mathrm{~mm}-\mathrm{Tris}-\mathrm{HCl}, \mathrm{pH}$ 7.5 containing $10 \mathrm{~mm}$-ethylenediaminetetra-acetic acid (EDTA) and boiling for $1 \mathrm{~min}$. The second incubation with Crotalus atrox venom (Sigma) and separation of nucleosides by batch adsorption were as previously described (Thompson \& Appleman, 1971). Enzyme concentration and time of reaction were adjusted so that no more than $20 \%$ of the substrates was hydrolysed. The assay condition to evaluate basal enzyme activity was chosen after preliminary experiments which showed that the addition of $\mathrm{Ca}^{2+}$ did not modify the enzyme activity profile obtained in the presence of EGTA, provided that chromatography had been performed in the presence of chelating agents. The calmodulin-enzyme complexes that are eluted from the column when $\mathrm{Ca}^{2+}$ is present during chromatography would be detected, in fact, as peaks of activity fully stimulated by the addition of $\mathrm{Ca}^{2+}$ alone to the assay mixture.

\section{Results}

\section{Phosphodiesterase forms in testes from immature and adult mice}

With the homogenization conditions employed, $90 \%$ of phosphodiesterase activity present in total homogenate was recovered in the cytosol, while $8 \%$ was present in the $20000 \mathrm{~g}$ pellet and only a trace amount was found in the $100000 \mathrm{~g}$ pellet.

Two main peaks of activity were resolved by ion-exchange chromatography of cytosol from 12day-old mouse seminiferous tubules (Text-fig. la, b). The first peak eluting at 130 mm-sodium acetate hydrolysed cGMP better than cAMP, and the activity was stimulated by $\mathrm{Ca}^{2+}$ and calmodulin. A second peak of activity eluting at $430 \mathrm{~mm}$-salt hydrolysed cAMP only, and the activity was not affected by calmodulin. A peak of activity hydrolysing mainly cGMP eluted at 250 mM-salt, and was almost insensitive to calmodulin stimulation $(\sim 30 \%)$. When chromatography was performed in the presence of $1 \mathrm{mM}-\mathrm{CaCl}_{2}$, the activity eluting at $130 \mathrm{~mm}$-salt was reduced while that eluting at $250 \mathrm{~mm}$ increased proportionally (data not shown). This indicated that the two activities represent the same enzyme form which shows different chromatographic behaviour when free or when bound to calmodulin, as described for the rat testis (Geremia et al., 1982).

Two main peaks of activity were present in cytosol from 60-day-old mouse seminiferous tubules (Text-fig. 1c, d) which are different from those found in the immature testis. A first peak of activity eluting at about $110 \mathrm{mM}$-sodium acetate hydrolysed both cAMP and cGMP at the same rate, and was stimulated by $\mathrm{Ca}^{2+}$ and calmodulin. A second peak of activity eluting at $350 \mathrm{~mm}$-sodium acetate hydrolysed cAMP only, and was insensitive to $\mathrm{Ca}^{2+}$ and calmodulin stimulation. Only trace amounts of cAMP hydrolysing activity could be detected at $430 \mathrm{mM}$ salt concentration.

The variation of stimulation was within $10 \%$ in different experiments. 


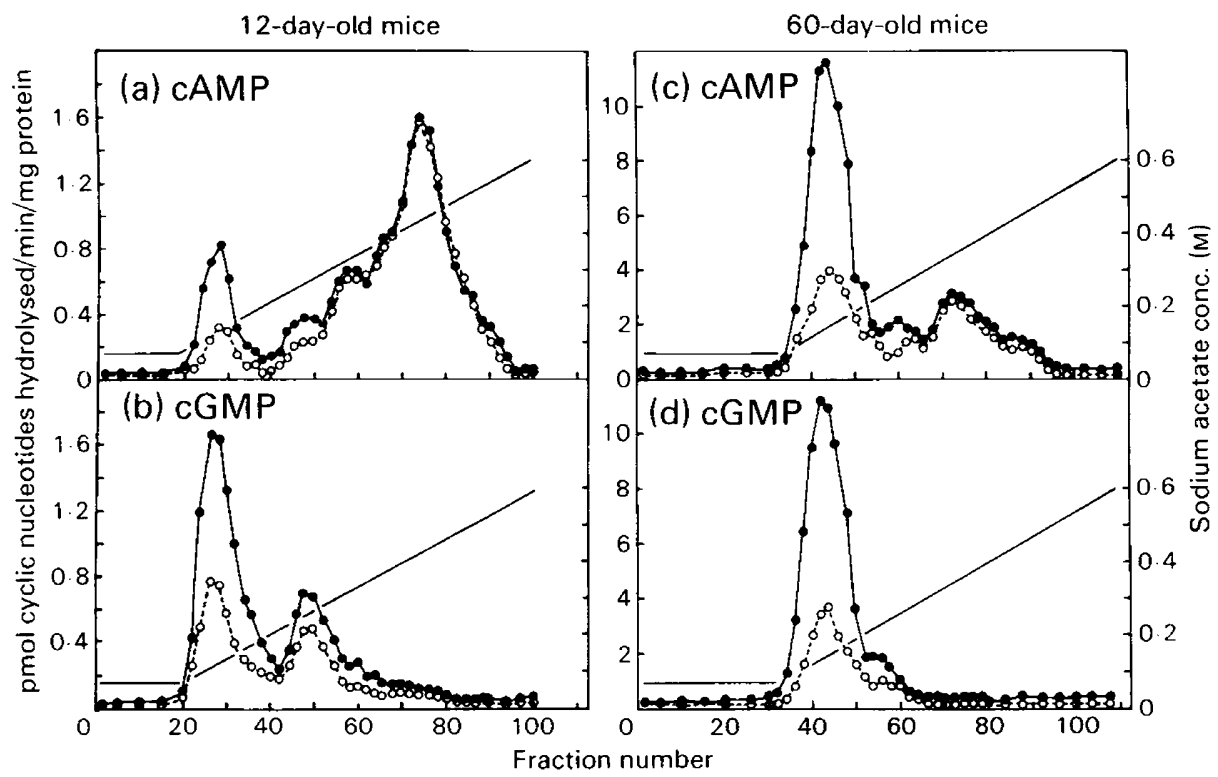

Text-fig. 1. Chromatographic patterns (representative of 3 different experiments) of phosphodiesterase activity from cytosol of seminiferous tubules from testes of 12-day-old and 60-day-old mice. Cyclic AMP (a, c) and cGMP (b, d) hydrolytic activity was measured in aliquants of the collected fractions in the presence of $1 \mu \mathrm{M}$ substrate and $1 \mathrm{mM}-\mathrm{CaCl}_{2}(\mathrm{O})$ or $1 \mathrm{mM}-\mathrm{CaCl}_{2}$ and calmodulin (O). See 'Materials and Methods' for details.

\section{Kinetic properties}

Lineweaver-Burk plots of substrate concentration studies of the calcium-calmodulindependent activity from immature mouse testis exhibited linear kinetics for both cAMP (Text-fig. 2a) and cGMP (Text-fig. 2b). The enzyme appeared to be a low-affinity form for cAMP (apparent $K_{\mathrm{m}} 20 \mu \mathrm{M}$ ) and a high affinity form for cGMP (apparent $K_{\mathrm{m}} 2 \mu \mathrm{M}$ ). Calmodulin enhanced $V_{\max } 4$ fold without affecting $K_{\mathrm{m}}$ values (data not shown). To establish whether this enzyme form possesses distinct catalytic sites for the two substrates, the effect of different concentrations of the nonradioactive form of a nucleotide on three different concentrations of the labelled form of the other nucleotide was studied. Text-figure $3(\mathrm{a}, \mathrm{b})$ represents Dixon plots $(1 / v$ versus [I]) of the experimental data showing a competitive inhibition of cAMP versus cGMP $\left(K_{\mathrm{i}} \sim 20 \mu \mathrm{M}\right)$ and vice vers $a\left(K_{\mathrm{i}} \sim 2 \mu \mathrm{M}\right)$, thus indicating that the two substrates are hydrolysed by the same catalytic site. Kinetic data on the calcium-calmodulin-dependent activity (110 mM-salt) from adult mouse testis have been reported elsewhere (Geremia, Rossi, Mocini, Pezzotti \& Conti, 1984). The enzyme from the adult mouse testis possessed substrate specificity characterized by high affinity for cGMP $\left(K_{\mathrm{m}} \sim 3.5 \mu \mathrm{M}\right)$, and cAMP $\left(K_{\mathrm{m}} \sim 2 \mu \mathrm{M}\right)$ and low affinity for cAMP $\left(K_{\mathrm{m}} \sim 20 \mu \mathrm{M}\right)$, and possessed distinct catalytic sites that interacted allosterically. Therefore $\mathrm{Ca}^{2+}$-dependent phosphodiesterases from adult and immature mouse testes are clearly distinct forms with regard to kinetic parameters.

Both calcium-calmodulin-independent forms showed specificity for cAMP which they hydrolysed with similar kinetics. The enzyme form from adult testis, eluting at $350 \mathrm{~mm}$-salt concentration, showed a $K_{\mathrm{m}}$ of $5 \mu \mathrm{M}$ (Text-fig. 2c) and that from immature testis, eluting at $430 \mathrm{~mm}$ salt, a $K_{\mathrm{m}}$ of $2 \mu \mathrm{M}$ (Text-fig. $2 \mathrm{~d}$ ). It was therefore possible to distinguish between these two forms on their different chromatographic behaviour. 


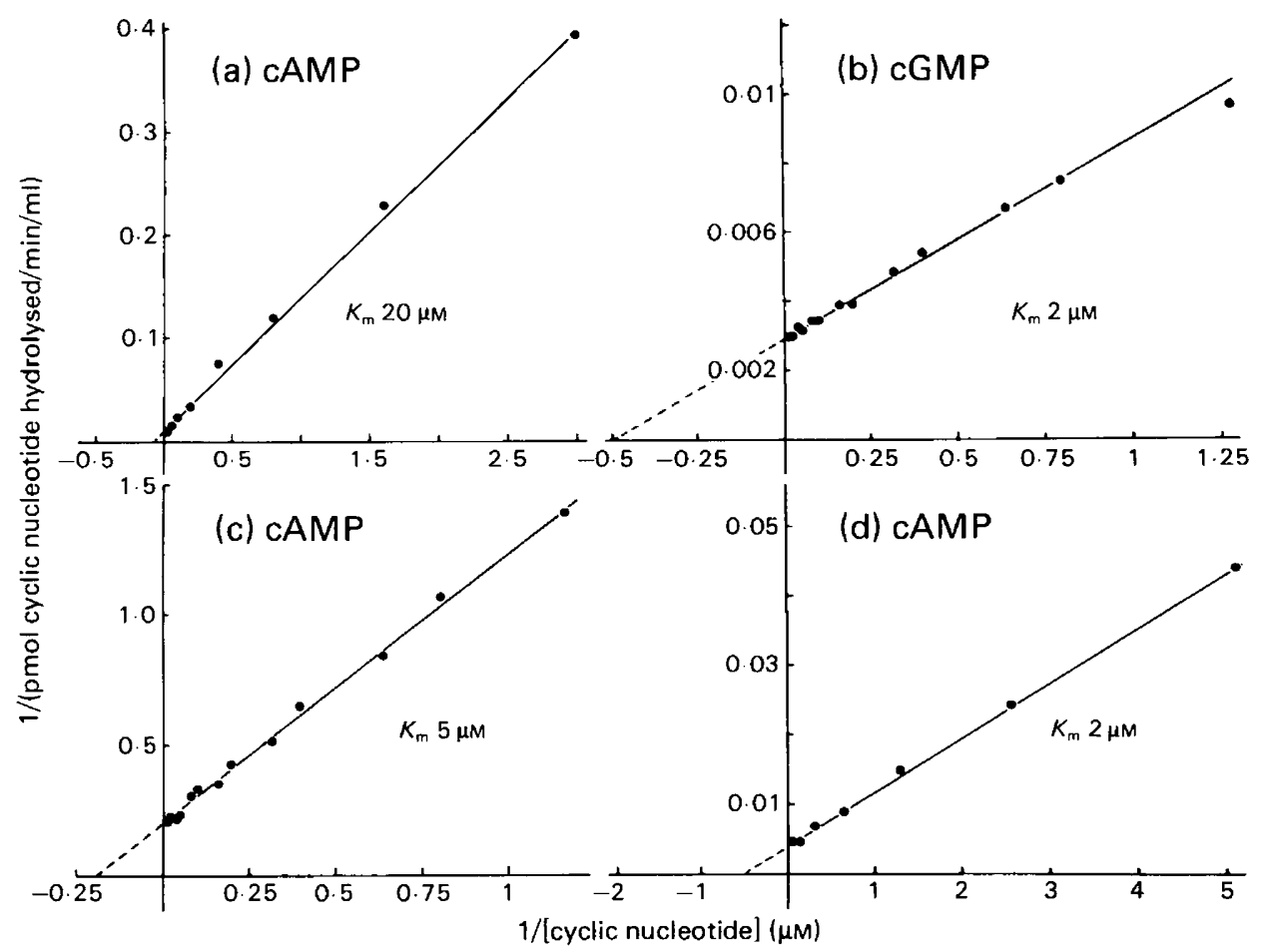

Text-fig. 2. Lineweaver-Burk plots of substrate concentration studies of the calciumcalmodulin-dependent phosphodiesterase from 12-day-old mice (130 mM-salt) and the calciumcalmodulin-independent forms (430 mM- and $350 \mathrm{~mm}$-salt) from 12-day- and 60-day-old mice, respectively. Pooled chromatographic fractions were used. The kinetic analysis of the calciumcalmodulin-dependent form from immature mice was performed with cAMP (a) and cGMP (b) as substrates, in the presence of $1 \mathrm{~mm}-\mathrm{CaCl}_{2}$ and calmodulin. The analysis of the calciumcalmodulin-independent forms from adult (c) and immature (d) mice was performed with cAMP as substrate. Each point was the mean of triplicate determinations from at least 2 experiments. The s.d. was within $10 \%$ of the mean value.

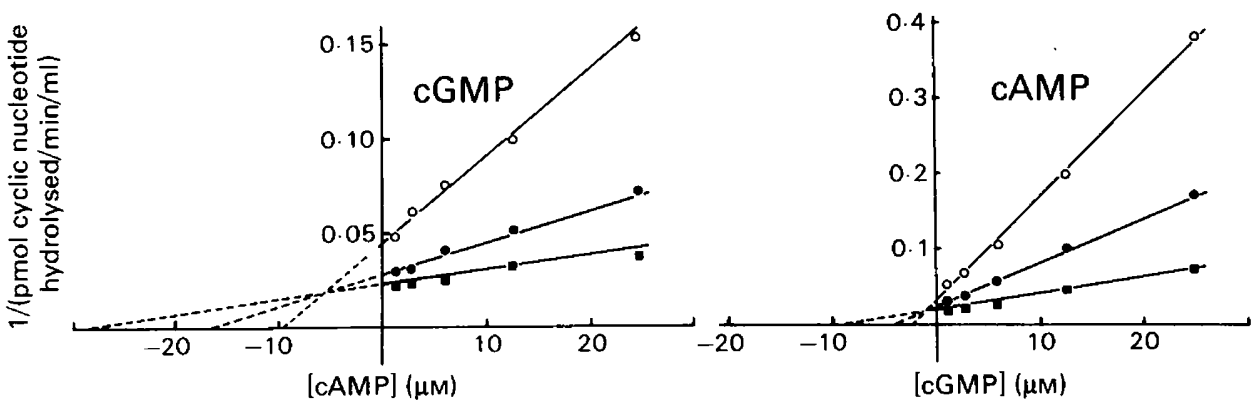

Text-fig. 3. Effect of different concentrations of the non-radioactive form of a nucleotide (abscissa) on the hydrolysis of the labelled form of the other (indicated in the panels) by the calcium-calmodulin-dependent phosphodiesterase (130 mM-salt) of testes of immature mice. Substrate concentrations were, $0.3 \mu \mathrm{M}(0), 0.6 \mu \mathrm{M}(O)$ and $1.2 \mu \mathrm{M}(\square)$. The reciprocal of enzyme activity measured in the presence of $1 \mathrm{mM}-\mathrm{CaCl}_{2}$ and purified calmodulin is shown on the ordinate, by Dixon plot (1/v versus [I]). Each point is the mean of triplicate determinations from 2 experiments. The s.d. was within $10 \%$ of the mean value. 
Distribution of phosphodiesterase forms in germ cells and somatic cells of the seminiferous tubule

To verify whether the different enzyme composition in the testes of adult and immature mice is the result of a selective distribution of phosphodiesterase forms in different cell types of seminiferous tubules, Sertoli cell cultures and germ cells at defined stages of development were studied.

The chromatographic pattern of phosphodiesterase activity from cytosol of cultured Sertoli cells (Text-fig. 4a) was similar to that observed in seminiferous tubules from the immature gonad: furthermore, the activity eluting at $130 \mathrm{~mm}$-salt hydrolysed cGMP only and was stimulated by calmodulin (data not shown) as in immature seminiferous tubules. The kinetics of enzyme activities from Sertoli cells were the same as those from immature gonads (data not shown). Experiments were also performed to verify whether the calcium-calmodulin-independent form of phosphodiesterase in mouse Sertoli cells is under FSH control as in the rat (Conti et al., 1982). Cyclic AMP hydrolysis in crude homogenates increased about 2-fold after 24-h incubation of Sertoli cells with $500 \mathrm{ng} \mathrm{FSH} / \mathrm{ml}$ while the calcium-calmodulin-dependent cGMP hydrolytic activity was unaffected (data not shown). The increase of enzyme activity seemed to be mediated by cAMP, because an augmentation of the specific activity of the calcium-calmodulin-independent form (430 mM-salt) was also obtained after incubation of Sertoli cells for $24 \mathrm{~h}$ with $1 \mathrm{~mm}$-dbcAMP (Text-fig. $4 \mathrm{~b}$ ).

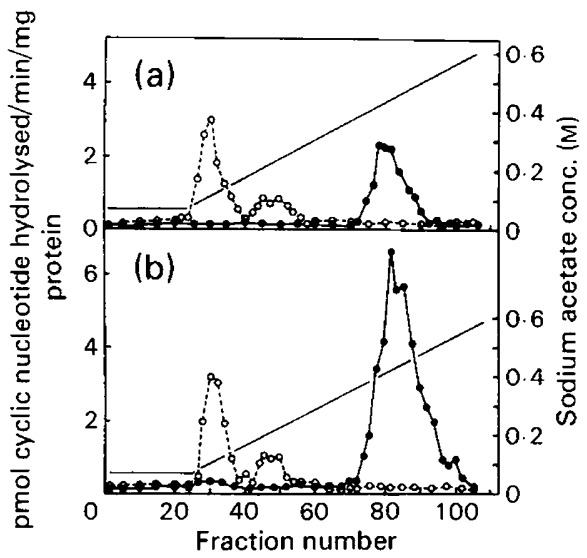

Text-fig. 4. Chromatographic patterns (representative of 2 different experiments) of phosphodiesterase activity from cytosol of control and dbcAMP stimulated Sertoli cell cultures. Cyclic AMP (O) and cGMP (O) hydrolytic activity was measured in (a) control cells and (b) after incubation for $24 \mathrm{~h}$ in the presence of $1 \mathrm{~mm}$-dbcAMP using $1 \mu \mathrm{M}$-substrate, in the presence of $1 \mathrm{mM}-\mathrm{CaCl}_{2}$ and calmodulin.

Chromatographic analysis of phosphodiesterase activity from cytosol of germ cell-enriched populations at different stages of development (Text-fig. 5a-f) exhibited patterns essentially similar to those observed for adult seminiferous tubules. The kinetics of enzyme activities from enriched germ cells were the same as those from adult testis (data not shown). Nonetheless, the profile changed at different stages of spermatogenesis : the calcium-calmodulin-dependent cAMPcGMP specific form (110 mM-salt) was present with the same specific activity in all differentiative stages considered; the calcium-calmodulin-independent cAMP specific form ( $350 \mathrm{mM}$-salt) was absent in meiotic stages (Text-fig. 5a), appeared and reached maximal specific activity in round spermatids (Text-fig. 5c) and declined in late spermiogenesis (Text-fig. 5e). 


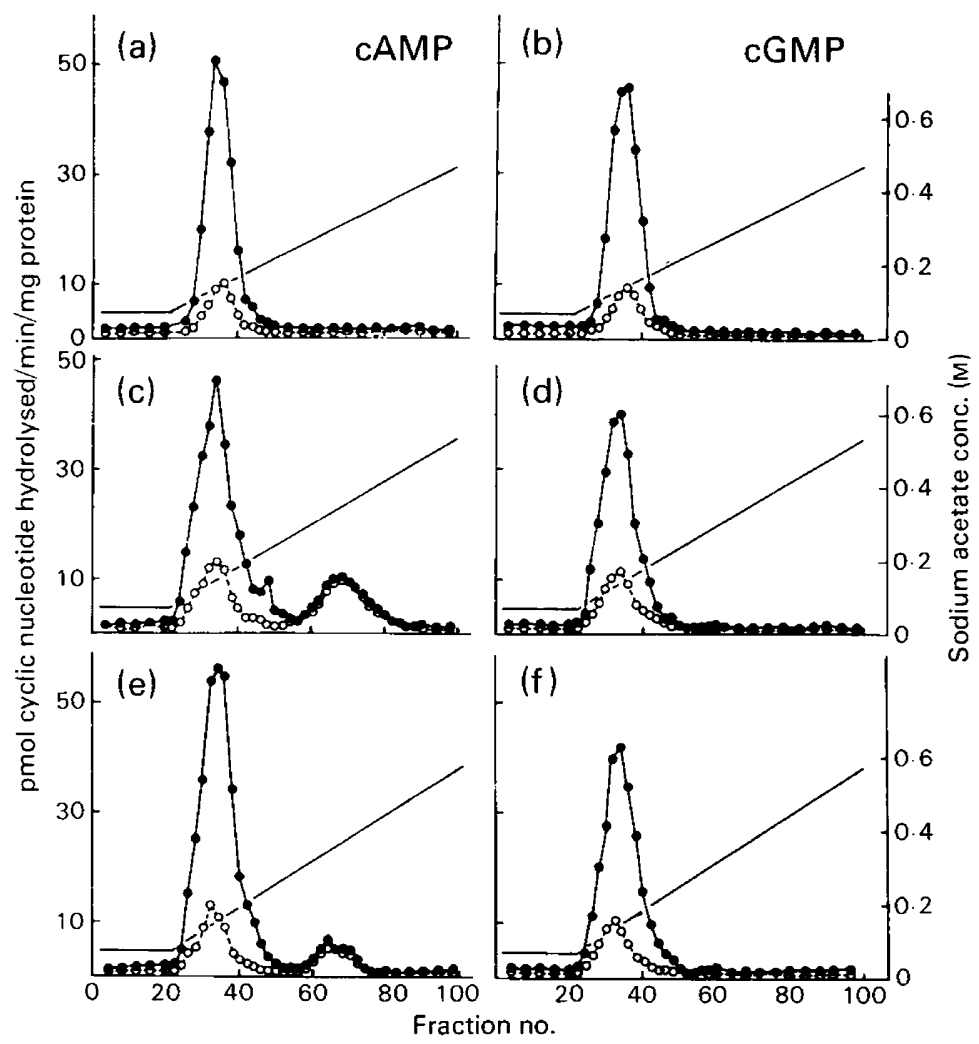

Text-fig. 5. Chromatographic analysis of phosphodiesterase activity from cytosol of germ cellenriched populations at different stages of development (patterns representative of 3 different experiments). The enzyme activity in middle-late pachytene spermatocytes $(a, b)$, round spermatids (c, d) and elongating spermatids (e, f) was measured using $1 \mu \mathrm{M}-\mathrm{cAMP}(\mathrm{a}, \mathrm{c}, \mathrm{e})$ and $1 \mu \mathrm{M}-\mathrm{cGMP}(\mathrm{b}, \mathrm{d}, \mathrm{f})$ as substrate, in the presence of $\mathrm{CaCl}_{2}$ alone $(\mathrm{O})$ or $\mathrm{CaCl}_{2}$ and calmodulin (O).

In addition, to establish whether the phosphodiesterase activities identified in germ cells can be found in other cell types of the mouse, chromatographic analyses of cytosol from spleen, brain, pancreas, kidney and heart were performed. None of the tissues showed a calcium-calmodulindependent cAMP-cGMP high-affinity phosphodiesterase or a calcium-calmodulin-independent cAMP-specific enzyme that eluted at $350 \mathrm{~mm}$-salt concentration (data not shown).

\section{Phosphodiesterase forms in epididymal spermatozoa}

Chromatographic analysis of cytosol showed the same enzyme activities present in differentiating germ cells, but the activity ratio between the two forms was changed, being approximately $1: 1$ (Text-fig. 6). The activity eluting at $110 \mathrm{~mm}$-salt was stimulated $2 \cdot 5$-fold by calmodulin (data not shown). Phosphodiesterase activity in epididymal spermatozoa appeared to be mainly present in the particulate fraction $(70-80 \%$ of total activity), unlike the observations for seminiferous tubules, Sertoli cells and differentiating germ cells. Most of the activity could be extracted by adding Triton X-100 at a final concentration of $1 \%$ to the homogenization buffer (data not shown). 


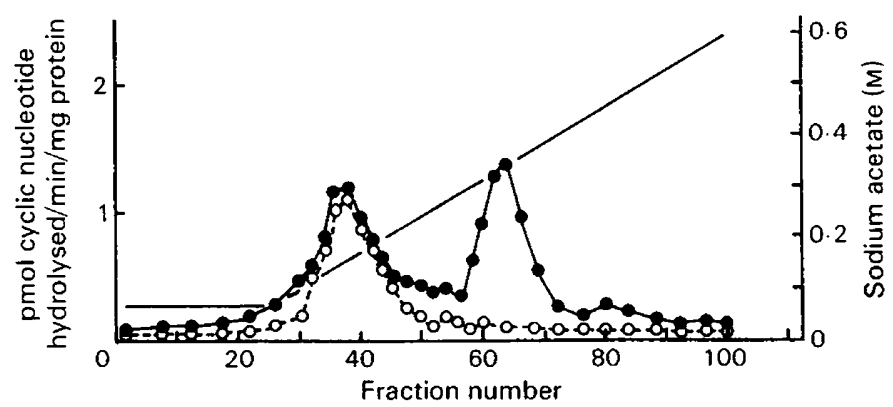

Text-fig. 6. Chromatographic analysis of phosphodiesterase activity from cytosol of epididymal spermatozoa (patterns representative of 2 different experiments). The activity was measured using $1 \mu \mathrm{M}$-cAMP (O) or $1 \mu \mathrm{M}$-cGMP $(O)$ as substrates, in the presence of $1 \mathrm{mM}$ $\mathrm{CaCl}_{2}$ and calmodulin.

\section{Discussion}

We have identified four phosphodiesterase forms in the mouse testis which can be distinguished on the basis of chromatographic behaviour and kinetic properties, and which display a distinct distribution in somatic and germ cells.

Somatic cells of the seminiferous tubules possess a calcium-calmodulin-dependent high-affinity cGMP phosphodiesterase eluting at $130 \mathrm{~mm}$-sodium acetate and a calcium-calmodulin-insensitive high-affinity cAMP enzyme eluting at $430 \mathrm{~mm}$-sodium acetate. They are the main forms found in seminiferous tubules from immature testes and in Sertoli cell-enriched cultures, while their activity is greatly reduced in the adult testis and absent in germ cell enriched preparations. The calciumcalmodulin-dependent enzyme activity is similar to that purified from bovine brain (Ho, Wirch, Stevens \& Wang, 1977; La Porte, Toscano \& Storm, 1979) and heart (Klee, Crouch \& Krinks, 1979; Sharma, Wang, Wirch \& Wang, 1980) and to a form described and characterized from rat testis (Geremia et al., 1982). This activity can be distinguished from the calcium-calmodulin-dependent form present in germ cells (Geremia et al., 1984). Substrate competition studies indicate, by the reciprocal competitive inhibition of $\mathrm{cAMP}$ and $\mathrm{cGMP}$, that the somatic cell form possesses a single catalytic site. However, the germ cell form possesses multiple hydrolytic sites in which cGMP and cAMP acted as non-competitive reciprocal inhibitors (Geremia et al., 1984). The calciumcalmodulin-independent phosphodiesterase of somatic cells (430 mM-salt) shows marked similarities with the hormone-regulated enzymes described for different tissues (for review, see Wells \& Hardman, 1977) and resembles an analogous form identified in Sertoli cells of the rat. The enzyme activity described herein displays the same chromatographic behaviour and kinetic properties as the rat enzyme and it can be also stimulated by exposure of mouse Sertoli cells in culture to FSH or dbcAMP; in the rat, this enzyme activity has been shown to be under FSH control both in vitro (Conti et al., 1981; 1982) and in vivo (Conti et al., 1983a).

Mouse germ cells possess a calcium-calmodulin-dependent phosphodiesterase with high affinity for cGMP (110 mM-salt) and high and low affinity for cAMP (Geremia et al., 1984), and a calcium-calmodulin-independent phosphodiesterase with high affinity for cAMP (350 mM-salt). These enzymes are found in seminiferous tubules from adult mouse testis and in enriched germ cell populations, while they are almost absent in seminiferous tubules from immature testis and in Sertoli cells in culture. Furthermore, these forms are absent in extracts of other mouse organs. The calcium-calmodulin-dependent cAMP-cGMP enzyme activity has been characterized elsewhere (Geremia et al., 1984) and it can probably be compared to similar forms described for different tissues from other species (see Beavo et al., 1982, for review). In the homogenization conditions 
used in this study most of the activity appeared to be in the cytosol of germ cells at all differentiative stages analysed with the exception of epididymal spermatozoa. Detergents are needed to solubilize the enzyme activity in spermatozoa, and further studies will be performed to establish whether the enzyme becomes particulate in this cell type. The calcium-calmodulin-independent phosphodiesterase with high affinity for cAMP shows chromatographic behaviour and kinetic properties similar to a germ cell-specific isoform described for the rat (Geremia et al., 1982), and it can be distinguished from the hormone-dependent form of the somatic cells mainly because it elutes at lower salt concentration. Furthermore, it undergoes quantitative variations during spermatogenesis that are similar to those described for the rat (Geremia, Rossi, Conti \& Stefanini, 1983b) and that correlate well with changes of intracellular cAMP levels during spermatogenesis (Adamo et al., 1980a). The highest enzyme specific activity is found in early spermatids in which the lowest cAMP levels are detectable. This enzyme activity probably corresponds to the enzyme activity described in developing rat testis (Monn, Desautel \& Christiansen, 1972) and in mature spermatozoa (Tash, 1976).

Even though it is not possible to speculate on the role of these enzyme activities in spermatogenesis, the finding that these phosphodiesterase forms are present in different species is of interest. Three activities are present in the rat (Purvis, Olsen \& Hansson, 1981; Geremia et al., 1982) and in the mouse (present study), i.e. the calcium-calmodulin-dependent form with highaffinity for CGMP (130 mM-salt) and the hormone-dependent form with high-affinity for cAMP in Sertoli cells (430 mM-salt), and the calcium-calmodulin-independent enzyme with high-affinity for cAMP in germ cells ( $350 \mathrm{mM}$-salt). In both species, the calcium-calmodulin independent enzyme shows similar quantitative variations during spermatogenesis. It is therefore tempting to speculate that these enzyme activities have a role in differentiative events of spermatogenesis. The fourth enzyme activity identified in mouse testis, i.e. the calcium-calmodulin-dependent form (110 mM salt) with high affinity for cAMP and cGMP, seems, on the contrary, to have a distribution that is species-specific. It is present and it represents a major form in germ cells of the mouse, while a similar form could not be identified in rat germ cells (Geremia et al., 1982), adult rat testis (Purvis $e t$ $a l ., 1981$ ) or testes from adult bulls, rabbits and trout (unpublished observations).

The two forms of phosphodiesterase identified in germ cells and specific to these cell types could represent genetic markers of spermatogenesis. Attempts are currently being made to purify germ cell-specific forms to establish whether they are gene products distinct from phosphodiesterase forms present in other tissues and cell types.

P.R. was recipient of a postdoctoral fellowship from "Fondazione Valerio Monesi". The work was supported by Ministero della Pubblica Istruzione, by CNR Targeted projects "Medicina Preventiva e Riabilitativa" and "Oncologia" and by NIH grant No. 1 RO1 HD18244 01.

\section{References}

Adamo, S., Conti, M., Geremia, R., Boitani, C. \& Monesi, V. (1980a) The cyclic nucleotide system in isolated male germ cells. In Animal Models in Human Reproduction, pp. 352-358. Eds M. Serio \& L. Martini. Raven Press, New York.

Adamo, S., Conti, M., Geremia, R. \& Monesi, V. (1980b) Particulate and soluble adenylate cyclase activities of mouse male germ cells. Biochem. Biophys. Res. Commun. 97, 607-613.

Beavo, J.A., Hansen, R.S., Harrison, S.A., Hurwitz, R.L., Martins, T.J. \& Mumby, M.C. (1982) Identification and properties of cyclic nucleotide phosphodiesterases. Molec. cell. Endocr. 28, 387-410.
Bensadoun, A. \& Weinstein, D. (1976) Assay of proteins in the presence of interfering materials. Analyt. Biochem. 70, 241-250.

Braun, T. (1974) Evidence for multiple cell-specific, distinctive adenylate cyclase systems in rat testis. In Hormone Binding and Target Cell Activation in the Testis, pp. 243-264. Eds M. L. Dufau \& A. R. Means. Plenum Press, New York.

Conti, M., Geremia, R., Adamo, S. \& Stefanini, M. (1981) Regulation of Sertoli cell cyclic adenosine $3^{\prime}: 5^{\prime}$ monophosphate phosphodiesterase activity by follicle-stimulating hormone and dibutyryl cyclic AMP. Biochem. Biophys. Res. Commun. 98, 1044-1050. 
Conti, M., Toscano, M.V., Petrelli, L., Geremia, R. \& Stefanini, M. (1982) Regulation by follicle-stimulating hormone and dibutyryl adenosine $3^{\prime}: 5^{\prime}$ monophosphate of a phosphodiesterase isoenzyme of the Sertoli cell. Endocrinology 110, 1189-1196.

Conti, M., Toscano, M.V., Petrelli, L., Geremia, R. \& Stefanini, M. (1983a) Follicle-stimulating hormone regulates in vivo testicular phosphodiesterase. Molec. cell. Endocr. 29, 79-89.

Conti, M., Toscano, M.V., Petrelli, L., Geremia, R. \& Stefanini, M. (1983b) Involvement of phosphodiesterase in the refractoriness of the Sertoli cell. Endocrinology 113, 1845-1853.

Dorrington, J.H., Roller, N.F. \& Fritz, I.B. (1975) Effects of follicle-stimulating hormone on cultures of Sertoli cells preparations. Molec. cell. Endocr. 3, 57-70.

Galdieri, M., Ziparo, E., Palombi, F., Russo, M.A. \& Stefanini, M. (1981) Pure Sertoli cell cultures: a new model for the study of somatic-germ cell interaction. J. Androl. 5, 249-254.

Geremia, R., D'Agostino, A. \& Monesi, V. (1978) Biochemical evidence of haploid gene activity in spermatogenesis of the mouse. Expl Cell Res. 111, 2330.

Geremia, R., Rossi, P., Pezzotti, R. \& Conti, M. (1982) Cyclic nucleotide phosphodiesterase in developing rat testis. Identification of somatic and germ cell forms. Molec. cell. Endocr. 28, 37-53.

Geremia, R., Mocini, D., Pezzotti, R., Conti, M. \& Rossi, P. (1983a) Cyclic AMP and cGMP phosphodiesterases in mouse testis. In Advances in Cyclic Nucleotide and Protein Phosphorylation Research, vol. 17A, p. 43. Eds P. Greengard \& G. A. Robinson. Raven Press, New York.

Geremia, R., Rossi, P., Conti, M. \& Stefanini, M. (1983b) Regulation of testicular phosphodiesterase during development and hormone treatment. In Recent Advances in Male Reproduction: Molecular Basis and Clinical Implications, pp. 121-128. Eds R. D'Agata, M. B. Lipsett, P. Polosa \& H. J. van der Molen. Raven Press, New York.

Geremia, R., Rossi, P., Mocini, D., Pezzotti, R. \& Conti, M. (1984) Characterization of a calmodulin-dependent high-affinity cyclic AMP and cyclic GMP phosphodiesterase from male mouse germ cells. Biochem. J. 217, 693-700.

Gordeladze, J.O. \& Hansson, V. (1981) Purification and kinetic properties of the soluble $\mathrm{Mn}^{2+}$-dependent adenylyl cyclase of the rat testis. Molec. cell. Endocr. 23, 125-136.

Gravis, C.J. (1978) Inhibition of spermiation in the syrian hamster using dibutyryl cyclic AMP. Cell Tiss. Res. 192, 241-248.

Ho, H.C., Wirch, E., Stevens, F.C. \& Wang, J.H. (1977) Purification of a $\mathrm{Ca}^{2+}$-activatable cyclic nucleotide phosphodiesterase from bovine heart by specific interaction with its $\mathrm{Ca}^{2+}$-dependent modulator protein. J. biol. Chem. 252, 43-50.

Hollinger, W.A. \& Hwang, F. (1974) Effect of dibutyryl cyclic AMP on in vitro rat testis DNA, RNA and protein labeling. Endocrinology 94, 444-449.

Jamieson, G.A., Jr \& Vanaman, T.C. (1979) Calcium dependent affinity chromatography of calmodulin on an immobilized phenothiazine. Biochem. Biophys. Res. Commun. 90, 1048-1056.
Klee, C.B., Crouch, T.H. \& Krinks, M.H. (1979) Subunit structure and catalytic properties of bovine brain $\mathrm{Ca}^{2+}$-dependent cyclic nucleotide phosphodiesterase. Biochemistry, N.Y. 18, 722-729.

Lam, D.M.K., Furrer, R. \& Bruce, W.R. (1970) The separation, physical characterization and differentiation kinetics of spermatogonial cells of the mouse. Proc. natn. Acad. Sci. U.S.A. 65, 192-199.

La Porte, D.C., Toscano, W.A. \& Storm, D.R. (1979) Cross-linking of Iodine-125-labeled, calcium-dependent regulatory protein to the $\mathrm{Ca}^{2+}$-sensitive phosphodiesterase purified from bovine heart. Biochemistry, N.Y. 18, 2820-2825.

Majumder, G.C. (1978) Occurrence of a cyclic AMPdependent protein kinase on the outer surface of rat epididymal spermatozoa. Biochem. Biophys. Res. Commun. 83, 829-836.

Matsumoto, K. (1983) Initiation of meiosis in yeast mutants defective in adenylate cyclase and cyclic AMP-dependent protein kinase. Cell 32, 417-423.

Means, A.R., Dedman, J.R., Tindall, D.J. \& Welsh, M.J. (1978) Hormonal regulation of Sertoli cell. Int. J. Androl., Suppl. 2, 1-19.

Means, A.R., Dedman, J.R., Tash, J.S., Tindall, D.J., Van Sickle, M. \& Welsh, M.J. (1980) Regulation of the testis Sertoli cells by follicle-stimulating hormone. Ann. Rev. Physiol. 42, 59-70.

Monn, E., Desautel, M. \& Christiansen, R.O. (1972) Highly specific testicular adenosine $3^{\prime}, 5^{\prime}$-monophosphate phosphodiesterase associated with sexual maturation. Endocrinology 91, 716-720.

Morrill, G.A., Zeigler, D. \& Kostellow, A.B. (1981) The role of $\mathrm{Ca}^{2+}$ and cyclic nucleotides in progesterone initiation of meiotic divisions in amphibian oocytes. Life Sci. 29, 1821-1835.

Purvis, K. \& Hansson, V. (1980) Hormonal regulation of spermatogenesis. Regulation of target cell response. Int. J. Androl., Suppl. 3, 82-143.

Purvis, K., Olsen, A. \& Hansson, V. (1981) Calmodulindependent cyclic nucleotide phosphodiesterases in the immature rat testis. J. biol. Chem. 256, 1143411441 .

Sanborn, B.M., Heindel, J.J. \& Robison, G.A. (1980) The role of cyclic nucleotides in reproductive processes. Ann. Rev. Physiol. 42, 37-57.

Schultz, R.M., Montgomery, R.R. \& Belanofi, J.R. (1983) Regulation of mouse oocyte meiotic maturation: implication of a decrease in oocyte cAMP and protein dephosphorylation in commitment to resume meiosis. Devl Biol. 97, 264-273.

Sharma, R.K., Wang, T.H., Wirch, E. \& Wang, J.H. (1980) Purification and properties of bovine brain calmodulin-dependent cyclic nucleotide phosphodiesterase. J. biol. Chem. 255, 5916-5923.

Spruill, W.A. \& Steiner, A.L. (1976) Immunohistochemical localization of cyclic nucleotides during testicular development. J. Cyclic Nucteotide Res. 2, 225-239.

Spruill, W.A., Steiner, A.L., Tres, L.L. \& Kierszenbaum, A.L. (1981) Temporal sequence of cell shape changes in cultured rat Sertoli cells after experimental elevation of intracellular cAMP. Expl Cell Res 131, $131-148$.

Tash, J.S. (1976) Investigation on adenosine $3^{\prime}: 5^{\prime}$-monophosphate phosphodiesterase in ram semen and 
initial characterization of a sperm-specific isoenzyme. J. Reprod. Fert. 47, 63-72.

Thompson, W.J. \& Appleman, M.M. (1971) Multiple cyclic nucleotide phosphodiesterase activities from rat brain. Biochemistry, N.Y. 10, 311-316.

Verhoeven, G., Cailleau, J. \& De Moor, P. (1980) Desensitization of cultured rat Sertoli cells by folliclestimulating hormone and by L-isoproterenol. Molec. cell. Endocr. 20, 113-126.
Verhoeven, G., Cailleau, J. \& De Moor, P. (1981) Hormonal control of phosphodiesterase activity in cultured rat Sertoli cells. Molec. cell. Endocr. 24, 4151.

Wells, J.M. \& Hardman, J.G. (1977) Cyclic nucleotide phosphodiesterase. Adv. Cyclic Nucleotide Res. 8, 119-144.

Received 31 May 1984 